\title{
Disseminated cysticercosis
}
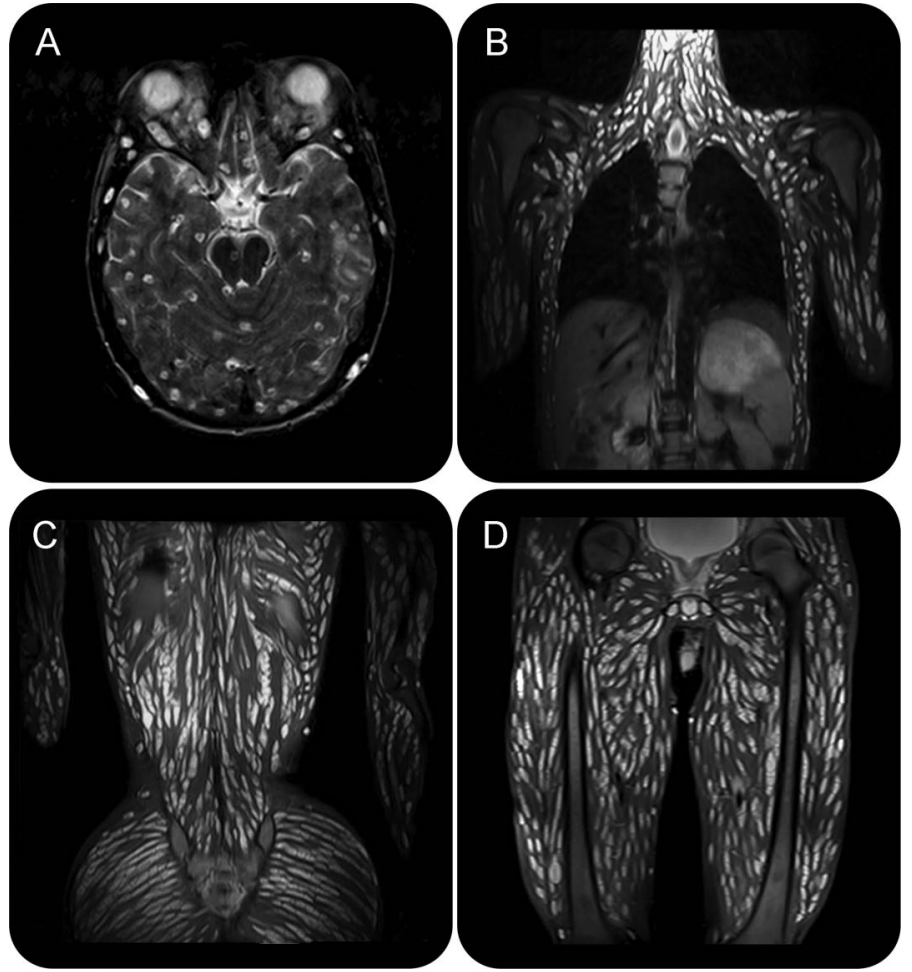

(A) Axial T2-weighted images show multiple cysticercus cysts in bilateral brain parenchyma, scalp, and extraocular muscles. (B-D) Coronal STIR images show extensive cysticercus cysts in neck, chest wall, abdominal wall, paraspinal, gluteal, pelvic, and limb muscles.

An 18-year-old boy presented with headaches, vomiting, recurrent seizures, and altered sensorium. He had extensive muscle hypertrophy on examination. MRI revealed multiple cysts in different stages in brain parenchyma, scalp, extraocular muscles, neck, chest wall, abdominal wall, paraspinal, gluteal, pelvic, and limb muscles (figure). The patient received steroids and antiepileptic drugs and had a good recovery. The patient is seizure-free at 6 months. In disseminated neurocysticercosis, symptoms are related to space-occupying effect rather than inflammation caused by dying parasites, and in this situation cysticidal drugs may exacerbate the syndrome of intracranial hypertension. ${ }^{1,2}$

Rajesh Jawale, $M D$, Dhananjay Duberkar, $M D, D M$

From S.M.B.T. Medical College (R.J.) and Wockhardt Hospitals (D.D.), Nashik, India.

Author contributions: Rajesh Dhanaraj Jawale: drafting/revising the manuscript, study concept or design, analysis or interpretation of data, accepts responsibility for conduct of research and final approval, contribution of vital reagents/tools/patients, acquisition of data, study supervision. Dhananjay Duberkar: drafting/revising the manuscript, accepts responsibility for conduct of research and final approval, acquisition of data. Study funding: No targeted funding reported.

Disclosure: The authors reported no disclosures relevant to the manuscript. Go to Neurology.org for full disclosures.

Correspondence to Dr. Jawale: drrajeshjawale@gmail.com

1. Wadia N, Desai S, Bhatt M. Disseminated cysticercosis: new observations, including CT scan findings and experience with treatment with praziquantel. Brain 1988;111:597-614.

2. Basu G, Surekha V, Ganesh A. Disseminated cysticercosis. Trop Doct 2009;39:48-49. 


\title{
Neurology
}

\author{
Disseminated cysticercosis \\ Rajesh Jawale and Dhananjay Duberkar \\ Neurology 2015;84;327 \\ DOI 10.1212/WNL.0000000000001152
}

\section{This information is current as of January 19, 2015}

\section{Updated Information \& Services}

\section{References}

Subspecialty Collections

Permissions \& Licensing

Reprints including high resolution figures, can be found at: http://n.neurology.org/content/84/3/327.full

This article cites 2 articles, 0 of which you can access for free at: http://n.neurology.org/content/84/3/327.full\#ref-list-1

This article, along with others on similar topics, appears in the following collection(s):

All Clinical Neurology

http://n.neurology.org/cgi/collection/all_clinical_neurology Parasitic infections

http://n.neurology.org/cgi/collection/parasitic_infections

Information about reproducing this article in parts (figures,tables) or in its entirety can be found online at:

http://www.neurology.org/about/about_the_journal\#permissions

Information about ordering reprints can be found online:

http://n.neurology.org/subscribers/advertise

Neurology ${ }^{\circledR}$ is the official journal of the American Academy of Neurology. Published continuously since 1951, it is now a weekly with 48 issues per year. Copyright () 2015 American Academy of Neurology. All rights reserved. Print ISSN: 0028-3878. Online ISSN: 1526-632X.

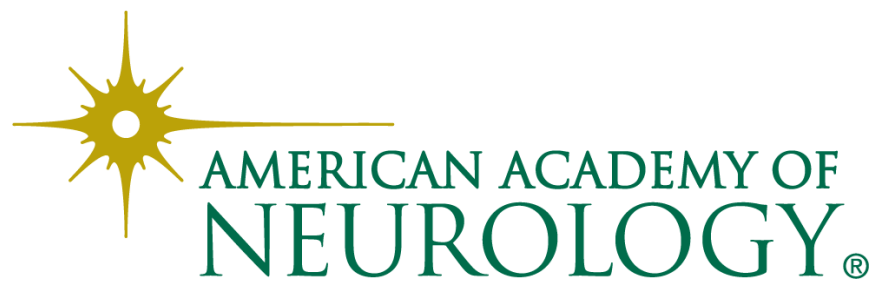

